\title{
Co-infection of bay scallops Argopecten irradians with Perkinsus karlssoni (Apicomplexa, Perkinsea) and an unidentified coccidian parasite
}

\author{
S. K. Whyte ${ }^{1}$, R. J. Cawthorn ${ }^{1}$, S. E. McGladdery ${ }^{2}$ \\ ${ }^{1}$ Department of Pathology and Microbiology, Atlantic Veterinary College, University of Prince Edward Island, \\ 550 University Avenue, Charlottetown, Prince Edward Island, Canada C1A 4P3 \\ ${ }^{2}$ Department of Fisheries and Oceans, PO Box 5030, Moncton, New Brunswick, Canada E1C 9B6
}

\begin{abstract}
A comparison of the coinfection of bay scallops with Perkinsus karlssoni and an as yet unidentified coccidian is described. P. karlssoni occurred in a range of host tissues including mantle, digestive gland, intestine, gill and gonad. Host tissue response elicited against $P$. karlssoni ranged from focal encapsulation by haemocytes to formation of abscesses filled with ceroid-containing cells. The coccidian was restricted to the kidney in light infections and occurred within the renal cells and the lumen of the renal tubules. In heavy infections the coccidian also occurred in the mantle, digestive gland, intestine, gill and gonad. There was no apparent host response elicited against the coccidian parasite regardless of the tissue in which it occurred or whether the parasite was intra- or intercellular. In dual infections, dense haemocytic encapsulation and infiltration by ceroid-containing cells masked the causative organism. Ultrastructural examination of lesions from concurrent infections revealed the presence of both parasites. Individual P. karlssoni infections were not found without a host response and the coccidian occurred with no apparent host response. It was therefore assumed that the response elicited in dual infections was caused predominantly by $P$. karlssoni.
\end{abstract}

KEY WORDS: Perkinsus · Coccidia $\cdot$ Bay scallop - Shellfish Histopathology

\section{INTRODUCTION}

Intensive molluscan aquaculture has led to the identification of a variety of infectious agents which adversely affect commercially important species. An understanding of the nature, pathogenesis and epidemiology of new diseases and disease agents is essential for the efficient development of this industry. Of all the infectious molluscan diseases known, those caused by the Protista have been most extensively studied as they tend to result in the most pronounced mortalities of commercially significant mollusc species (Perkins 1993).

One such etiologic disease agent which has been intensively studied since it was first discovered in 1948 (Mackin et al. 1950) is the apicomplexan parasite Perkinsus marinus. Disease caused by this parasite continues to have a serious impact on eastern (= American) oyster Crassostrea virginica culture in the
Gulf and Atlantic coasts of the United States. An extensive review of the epidemiology and pathology of this disease is provided by Lauckner (1983) and Andrews (1988). The initial host response to infection with $P$. marinus is a marked haemocytosis and migration of phagocytes to the sites of parasite lodgement resulting in extensive inflammation (Lauckner 1983). P. marinus becomes systemic early in the disease and does not manifest moribund features in the oyster until there are more than $10^{6}$ parasites $\mathrm{ml}^{-1}$ of haemolymph. Progression of the disease results in loss of adductor muscle control and gaping of the shell with an associated pallor and shrinkage of affected tissues.

In addition to Perkinsus marinus, 3 other Perkinsus species have been described; $P$. atlanticus, $P$. olseni and P. karlssoni. P. atlanticus occurs in the Portuguese clam Ruditapes decussatus (Azevedo 1989, 1990). There is a paucity of information regarding its pathogenesis and epidemiology although it is reported to 
cause severe losses (Chagot et al. 1987. Comps \& Chagot 1987). P. olseni has been found in the adductor muscle of the blacklipped abalone Haliotis ruber but can also occur free in the haemolymph (Lester \& Davis 1981). The inflammatory response to this parasite can result in the formation of abscesses up to $10 \mathrm{~mm}$ in diameter (Lester et al. 1990). P. karlssoni was described in the bay scallop Argopecten irradians (McGladdery et al. 1991). The host response to this parasite ranges from focal haemocytic encapsulation to formation of abscesses containing necrotic haemocytes, parasites and ceroid-containing cells (McGladdery et al. 1991). Several other Perkinsus spp. have been reported in as many as 67 species of molluscs; all bivalves except for 4 species of gastropod (Perkins 1993). The pathogenicity of these or yarrisms has yet to bo clucidated as dees the current controversy as to whether one or more species of Perkinsus are involved (Perkins 1993).

In contrast to the extensive work carried out on Perkinsus spp., very little is known about the coccidian parasites which infect molluscs, in particular bivalves. A small number of coccidia have been observed in molluscs, three of which have been speciated in bivalves (Morado et al. 1984). These include Hyaloklossia pelseneeri in Donax sp. and Tellina sp. (northern dwarf tellin) from France (Léger 1897), Pseudoklossia glomerata in the kidney of Tapes floridus and $T$. virgineus (littleneck clams) (Léger \& Duboscq 1917) and $P$. pectinis in the kidney of the great scallop Pecten maximus. Coccidia have been suspected to be present in other bivalves but have not been identified; Tige et al. (1977) identified a coccidian in the renal cells of the flat oyster Ostrea edulis, Wolf (1977) suspected a coccidian infection in the blacklipped oyster Crassostrea echinata, and Meyers (1.981) suspected a coccidian infection in the eastern oyster $C$. virginica. Unidentified coccidian infections have also been reported in captive and cultured adult bay scallops (Leibovitz et al. 1984, Getchell 1991, Karlsson 1991). Most reports of coccidian infections in bivalve molluscs have, however, been taxonomic or life history studies with very few concentrating on the pathology of the infection (Sparks 1985). In those instances where pathology was described both the intensity of infection and host response varied considerably.

This paper compares the tissue response of the bay scallop to co-infection by Perkinsus karlssoni and an unidentified coccidian parasite.

\section{MATERIALS AND METHODS}

Laboratory maintenance of bay scallops. Approximately 775 bay scallops were collected directly from 2 broodstock hatcheries: one in Prince Edward Island
(PEI), Canada, and the other in Nova Scotia, Canada, and introduced into the quarantine facility at the Atlantic Veterinary College (AVC), Charlottetown, PEI. A random sample ( $10 \%$ of the total number) was removed and processed for thioglycollate culture and histology in order to assess the disease status of these scallops. Early on in the experiment, routine histopathological and electron microscopical evaluation revealed co-infection with an unidentified parasite. Ultrastructural characteristics of this parasite were consistent with the coccidian group (unpubl. obs.). The 2 groups of scallops were maintained together in the facility to provide a source of parasitic material for use in concurrent research projects.

The 2 groups of bay scallops were distributed into separate lantern nets within the same closed-circulation saltwater (Instant Ocean) tank. Water temperatures were maintained between 20 and $25^{\circ} \mathrm{C}$ and salinities ranging from 27 to $31 \%$. Scallops were fed daily on a diet of cultured algae (Chaetoceros gracilis and Tahitian isochrysis) and SDA ${ }^{1}$ [Spray Dried Algae (Tetraselmis) Cell Systems Ltd, Orwell House, Cowley Road, Cambridge CB4 4WY, UK]. Mortalities were also recorded daily. Random samples $(10 \%$ of original total of 775) were removed periodically over a $6 \mathrm{mo}$ period and processed for both light and electron microscopy.

Light microscopy. Transverse sections of whole bay scallops were collected and fixed in a solution of 1 part glutaraldehyde: 4 parts formalin for $24 \mathrm{~h}$ followed by paraffin-infiltration and embedding (Howard \& Smith 1983). Sections (5 to $7 \mu \mathrm{m}$ ) were stained with Harris' modified haematoxylin and $0.5 \%$ alcoholic eosin $y$ (McGladdery et al. 1991).

Electron microscopy. Tissue samples (digestive gland, rectum, gill, mantle and kidney) were excised and fixed in $3 \%$ glutaraldehyde in $0.1 \mathrm{M}$ sodium cacodylate buffer, pH 7.8 , for 24 h at $4^{\circ} \mathrm{C}$. Fixed tissues were washed for $2 \mathrm{~h}$ at $4{ }^{\circ} \mathrm{C}$ in the same buffer and cut into $1 \mathrm{~mm}^{3}$ pieces. These were then post-fixed in buffered $2 \% \mathrm{OsO}_{4}$ for $2 \mathrm{~h}$ at the same temperature, dehydrated through a series of ethanols and embedded in Epon. Sections (90 nm thickness) were cut and stained with $5 \%$ uranyl acetate for $30 \mathrm{~min}$ and lead citrate for 2 min, and observed with a Hitachi 7000 operated at $75 \mathrm{kV}$

\section{RESULTS}

\section{Perkinsus karlssoni}

The presence of the parasite elicited a multifocal inflammatory response in all affected organs: mantle, digestive gland, gill, gonad and kidney. Lesions con-

\footnotetext{
${ }^{1}$ No longer available
} 




- $\log ^{2} \mathrm{C}^{2}$
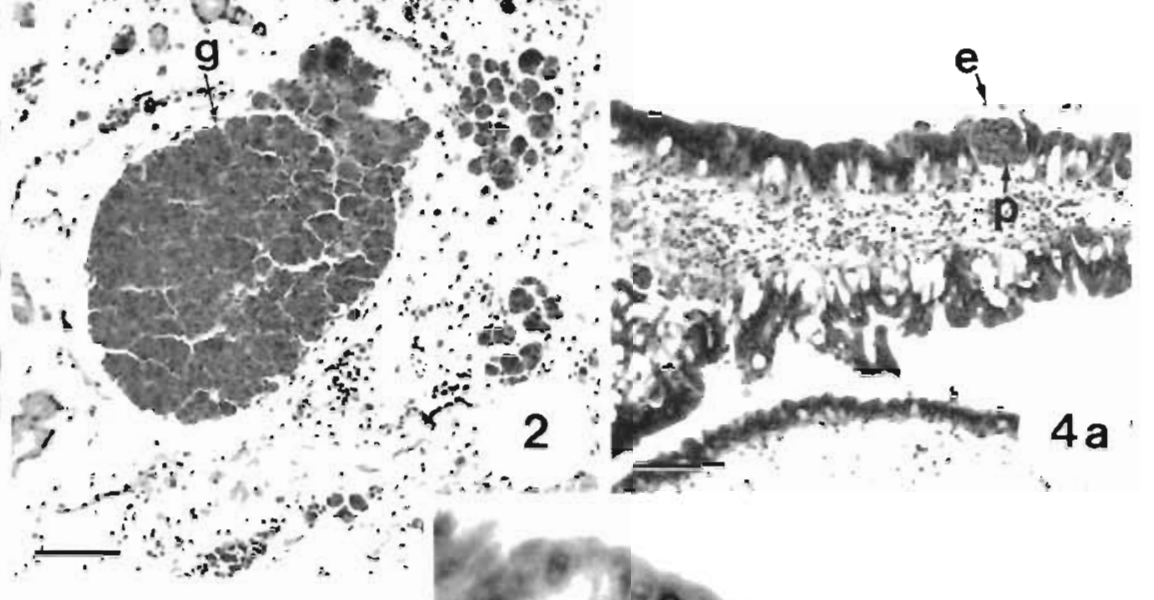

a

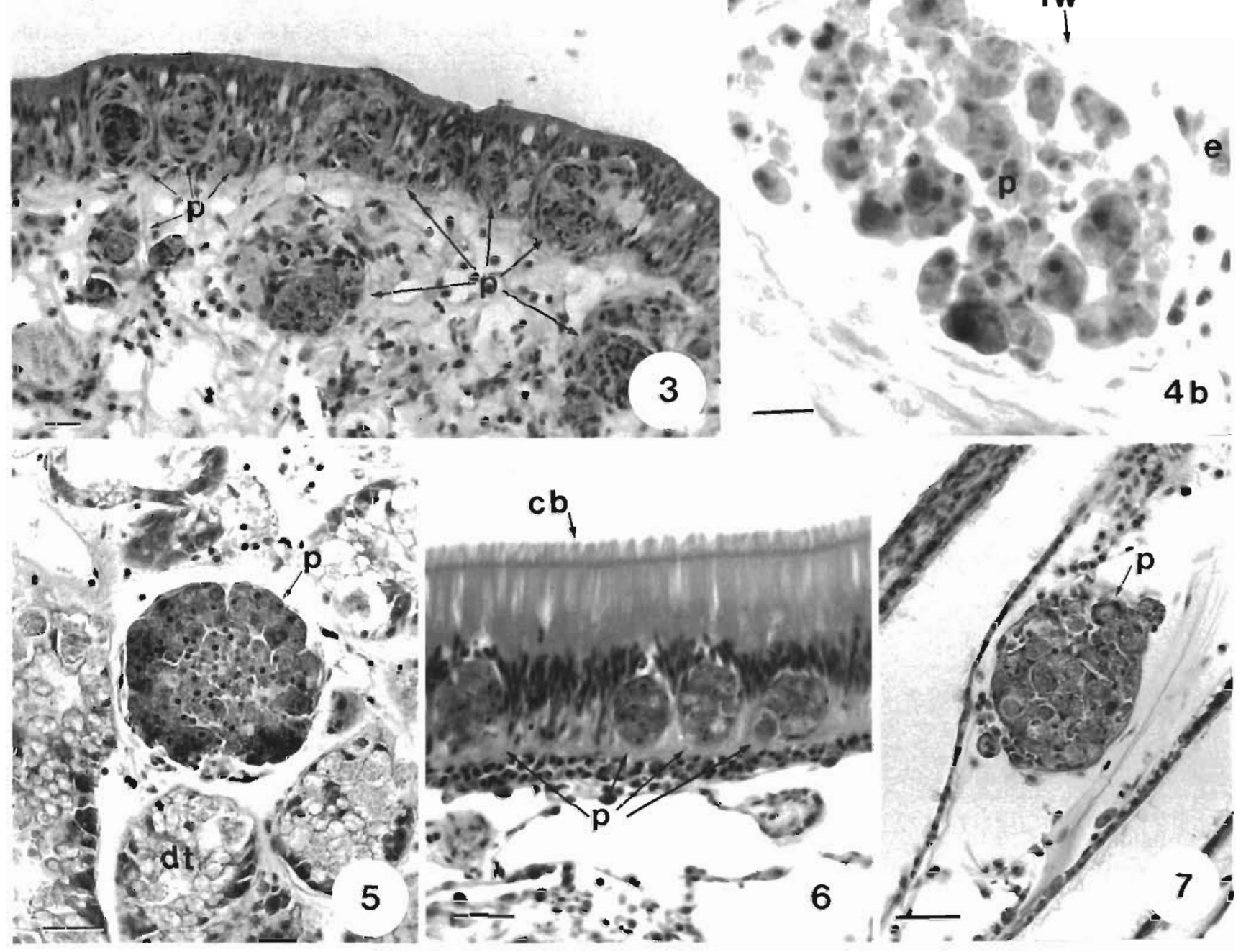

Figs 1 to 7. Perkinsus karlssoni infecting Argopecten irradians. Fig. 1 P. karlssoni (p) in the connective tissue of the digestive gland surrounded by host haemocytes $(\mathrm{h})$ in a swirl-like encapsulation response $(\mathrm{H} \& \mathrm{E}$; scale bar $=8.5 \mu \mathrm{m})$. Fig. 2 . P. karlssoni lesions coalesced into a large aggregation of parasites $(\mathrm{g})\left(\mathrm{H} \& \mathrm{E}_{\mathrm{i}}\right.$ scale bar $\left.=54 \mu \mathrm{m}\right)$. Fig. 3. P. karlssoni 'swirl lesions $(\mathrm{p})$ in the connective tissue below the mantle margin and also between the cells of the mantle epithelium $\left(\mathrm{H} \& \mathrm{E}_{;} \mathrm{scale} b a r=30 \mu \mathrm{m}\right)$. Fig. 4. P. karlssoni 'swirl' lesions located in the epithelium of the mantle. (a) Parasite lesion is circumscribed by a single epithelial

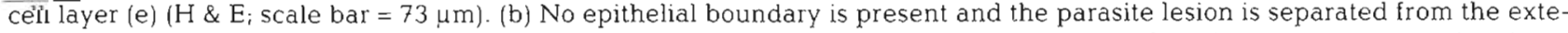
rior only by the fibrous wall of the parasite aggregate $(1 w)\left(H \& E_{;}\right.$scale bar $\left.=11 \mu \mathrm{m}\right)$. Fig. 5 . P. karlssoni $(p)$ in connective tissue of digestive gland between digestive tubules (dt) $(\mathrm{H} \& \mathrm{E}$; scale bar $=26 \mu \mathrm{m}$ ). Fig. $6 . P$. karlssoni $(\mathrm{p})$ located between the cells of the intestinal epithelium eliciting an encapsulation response but having no effect upon the ciliated border (cb) of the epithelium

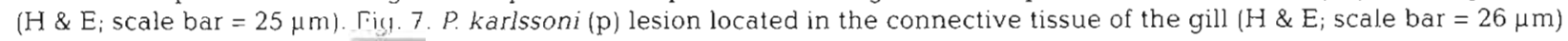


sisted primarily of a swirl-like encapsulation by host haemocytes and varied from focal to multifocal within the affected tissues (Fig. 1). In heavy infections, parasitic lesions coalesced to form lesions which ranged from 50 to $300 \mu \mathrm{m}$ in diameter (Fig. 2). Identification of the parasite within the lesion was not always possible, even at the ultrastructural level, due to variable deposition of necrotic debris and infiltration of ceroid-containing cells. Heavily parasitized bay scallops appeared to possess more ceroid-containing cells than lightly parasitized specimens.

Swirl-like parasitic lesions were observed in the connective tissue of the mantle, immediately beneath the mantle margin, and in the epithelial tissue of the mantle margin (Fig. 3). In some instances there was an absence of a host haemocytic respnnse and aggregrations of the parasite were observed to be circumscribed within the mantle by either a thin single cell layer (Fig. 4a) or were separated from the exterior only by the fibrous tissue which surrounded the parasites and contained them within a distinct lesion (Fig. 4b).

Although parasitic lesions were observed in the connective tissue of the digestive gland (Fig. 5), none were noted in the adjacent digestive tubulcs cithor within the lumen or the tubule epithelium. Encapsulated parasites were also present within the intestinal mucosa, causing no damage to the ciliated border (Fig. 6). Connective tissues of the gill (Fig. 7), the testis (Fig. 8a), the ovaries (Fig. 8b) and the kidney were also infected. In the kidney, Perkinsus karlssoni was consistently found in association with the unidentified coccidian infection (Fig. 9)

\section{Unidentified coccidian infection}

Normal kidney epithelium of the bay scallop is extensively infolded forming blind-ended sacs comprised of tall ciliated columnar cells underlaid by a basement membrane and a network of loose connective tissue (Fig. 10). In mild infections the parasite was restricted intracellularly within renal epithelium, causing slight intracellular vacuolation but no haemocytic infiltration. The parasite occupied most of the intra- cellular cell space of the columnar cells of the epithelial tissue.

In heavy infections severe vacuolative distortion of the renal architecture was noted due to the physical accumulation of the coccidian (Fig. 11). Electron microscopy revealed that the nucleus of the cell was compressed to one side while the parasite occupied the remainder of the cell space (Fig. 12a). In some instances vacuoles were evident in the cytoplasm surrounding the parasite (Fig. 12b). In severe infections the coccidian was not restricted to the kidney but could be found both intra- and intercellularly in the gill (Fig. 13), seminiferous tubules (Fig. 14a), ovarian follicles (Fig. 14b), intestinal epithelium (Fig. 15a) and digestive tubule epithelium and lumen (Fig. 15b).

In general, intracellular parasitism of epithelial tissue did not disrupt ciliary borders; although disruption was recorded in a few, severely infected individuals (Fig. 16a, b).

In dual infections, Perkinsus karlssoni and the coccidian parasite were observed within the same lesion (Fig. 17) as well as separately. These lesions were disseminated throughout all organs being most prevalent in connective rather than epithelial tissues. Ultrastructurally $P$. karlssoni was identified as the dominant parasitic component of the lesions (Fig. 18a). Unlike $P$. karlssoni the coccidia found within the lesion appeared undamaged, while the coccidia outside the realm of the host response failed to elicit any tissue response of their own (Fig. 18b).

\section{DISCUSSION}

The host tissue response observed in bay scallops infected with Perkinsus karlssoni is comparable with that described for $P$. marinus in some species of bivalves (Mackin 1951, Sparks 1985). P. karlssoni was encapsulated by successive layers of host haemocytes which flattened out, isolating the parasite from surrounding tissue. A characteristic 'swirl' lesion often developed in the early stages of the infection but appeared to be lost as the lesion increased in size. This was also noted by Perkins (1976) in American (= eastern) oysters

Figs. 8 to 13. Perkinsus karlssoni and a coccidian parasite infecting Argopecten irradians. Fig. 8. P. karlssoni (p) in connective tissue of (a) the testis between seminiferous tubules $\left(H \& E_{i}\right.$ scale bar $=30 \mu \mathrm{m}$ ); (b) the ovary (o). Mature ova (e) are not affected $\left(\mathrm{H} \& \mathrm{E}_{\mathrm{i}}\right.$ scale bar $\left.=27 \mu \mathrm{m}\right)$. Fig. 9. P. karlssoni $(\mathrm{p})$ lesion located in the interstitial spaces between the kidney tubules. The coccidian (c) occurs intracellularly within the renal cells of the kidney and occasionally in the interstitial spaces ( $\mathrm{H} \& \mathrm{E}_{\text {; }} \mathrm{scale}$ bar $\left.=25 \mu \mathrm{m}\right)$. Fig. 10. Normal kidney architecture of bay scallop $\left(H \& E_{i}\right.$ scale bar $\left.=22 \mu \mathrm{m}\right)$. Fig. 11 . The coccidian (c) within the renal cells of the kidney and in the lumen of the kidney tubules. No inflammatory response is present (H\& $E_{;}$scale bar $\left.=22 \mu \mathrm{m}\right)$. Fig. 12 . Electron micrograph of the coccidian (c) occupying a renal cell. (a) The host nucleus (hn) is displaced to one end of the cell as the parasite occupies the remaining space. $(\times 6000)$. Cm: host cell membrane; cn: parasite nucleus. (b) The cytoplasm surrounding the parasite is vacuolated. $(\times 14600)$. Fig. 13. The coccidian $(c)$ in the connective tissue of the gill with no host inflammatory response $\left(H \& E_{i}\right.$ scale bar $\left.=29 \mu \mathrm{m}\right)$ 


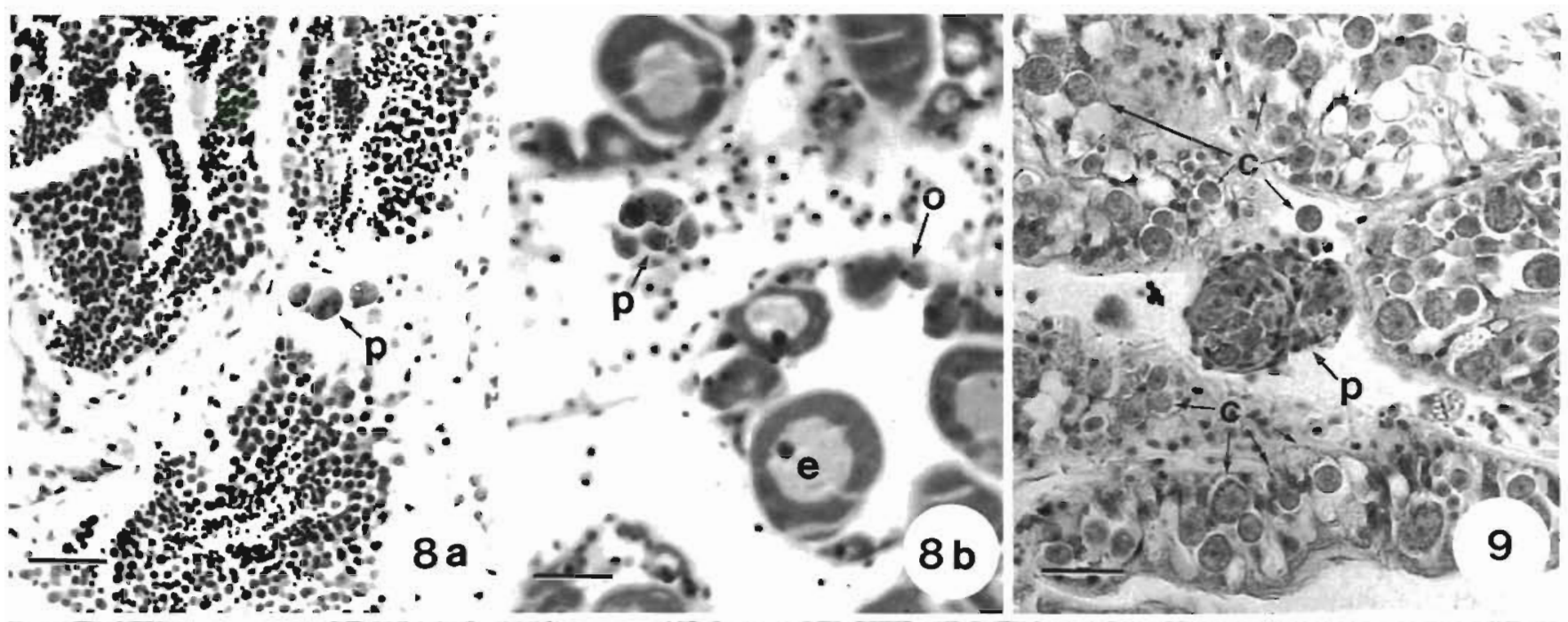

3.

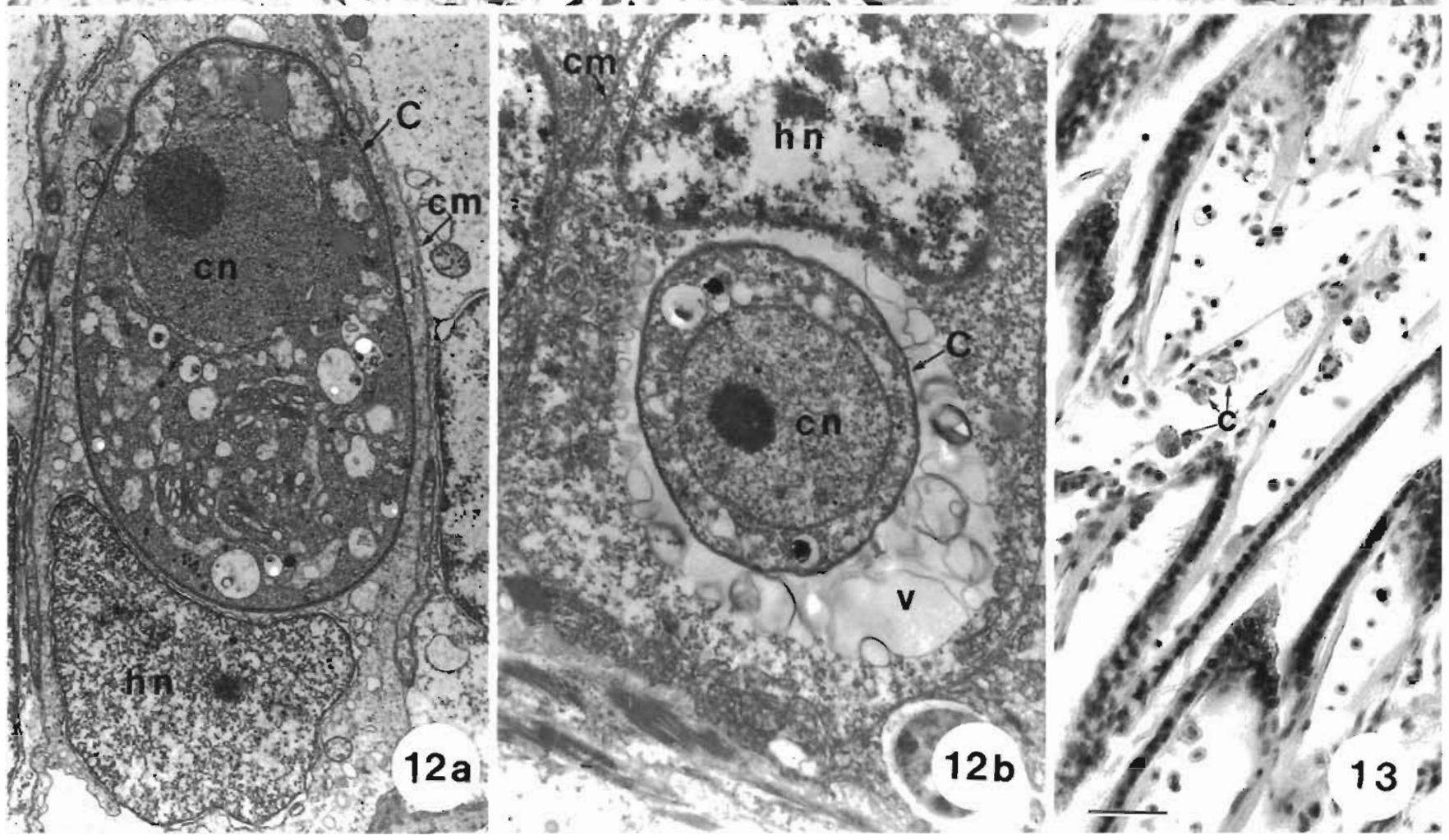




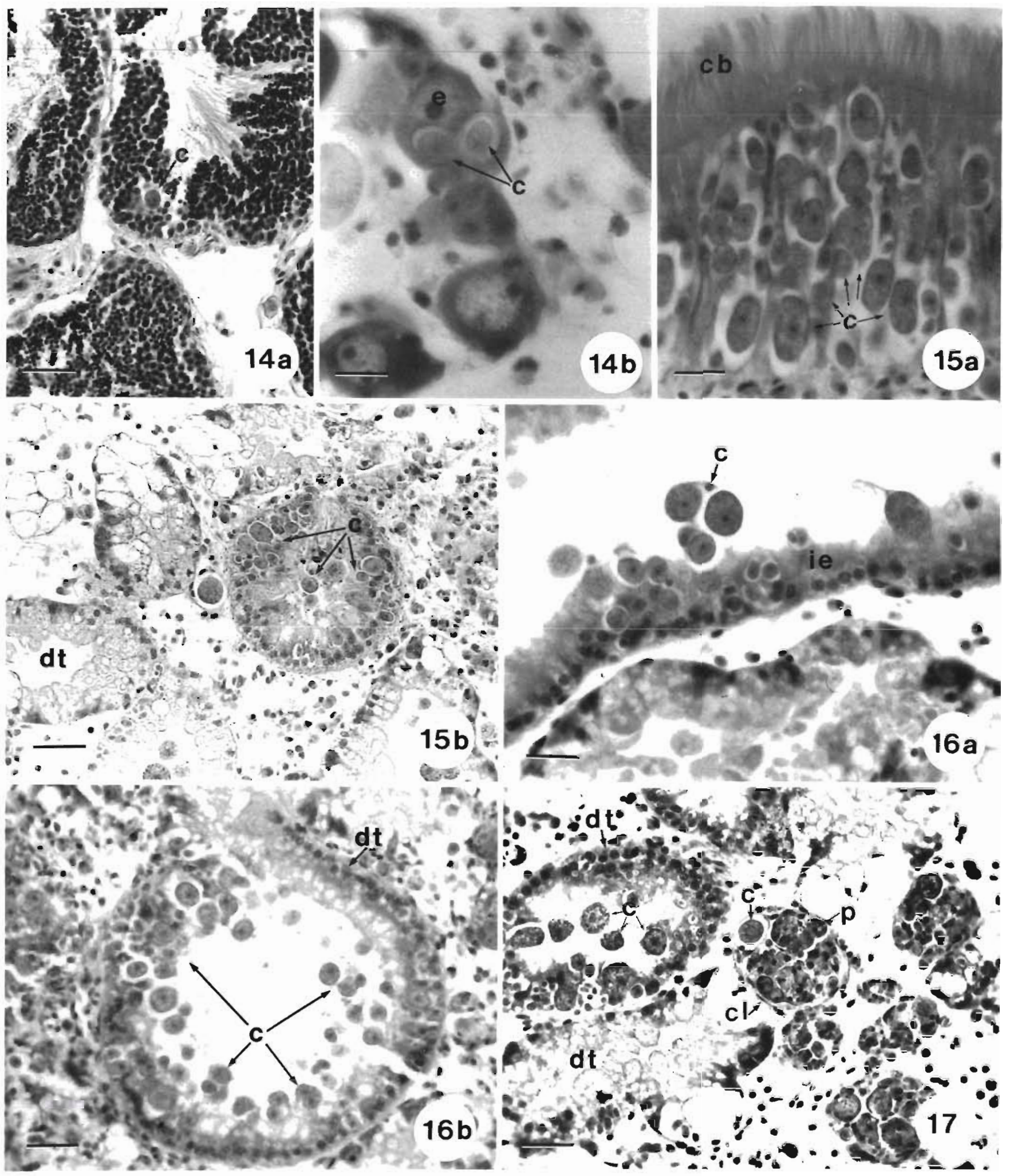

Figs. 14 to 17 Perkinsus karlssoni and a coccidian parasite infecting Argopecten irradians. Fig. 14. (a) The coccidian (c) within a seminiferous tubule $\left(H \& E_{i}\right.$ scale bar $\left.=14 \mu \mathrm{m}\right)$. (b) The coccidian parasite $(c)$ within an individual ovum $(e)\left(H\right.$ \& $E_{i}$ scale bar $=$ $25 \mu \mathrm{m}$ ). Fig. 15. (a) The coccidian parasite (c) within the cells of the intestinal epithelium. The ciliated border (cb) of the intestinal epithelium is unaffected $\left(\mathrm{H} \& E_{i}\right.$ scale bar $\left.=11 \mu \mathrm{m}\right)$. (b) The coccidian parasite (c) within intact cells of the digestive tubule (dt) epithelium and within the tubule lumen. The coccidian is also present in the connective tissue between the tubules ( $\mathrm{H} \& \mathrm{E}$; scale bar $=31 \mu \mathrm{m}$ ). Fig. 16. (a) Intestinal mucosa infected with the coccidian parasite (c) lacking a ciliated border with necrotic epithelial cells ( $\mathrm{H} \& \mathrm{E}$ : scale bar $=18 \mu \mathrm{m}$ ). (b) An infected digestive tubule (dt) with the coccidian parasite (c) located in the necrotic epithelium of the tubule and in the lumen of the tubule ( $\mathrm{H} \& \mathrm{E}$; scale bar $=17 \mu \mathrm{m}$ ). Fig. 17. A combined infection of P. Karlssoni (p) and the coccidian parasite (c) in the digestive gland. (dt) Digestive tubule (H \& E; scale bar $=12 \mu \mathrm{m}$ ) 
Fig. 18. Perkinsus karlssoni and a coccidian parasite infecting Argopecten irradians. (a) Electron micrograph of a parasite lesion consisting of Perkinsus karlssoni (pl) and the coccidian parasite (c) $(\times 3200)$ (b) Electron micrograph of a parasite lesion in response to $P$. karlssoni (pl) with the coccidian parasite $(c)$ outside the lesion remaining unaffected and eliciting no host response $(\times 3200)$

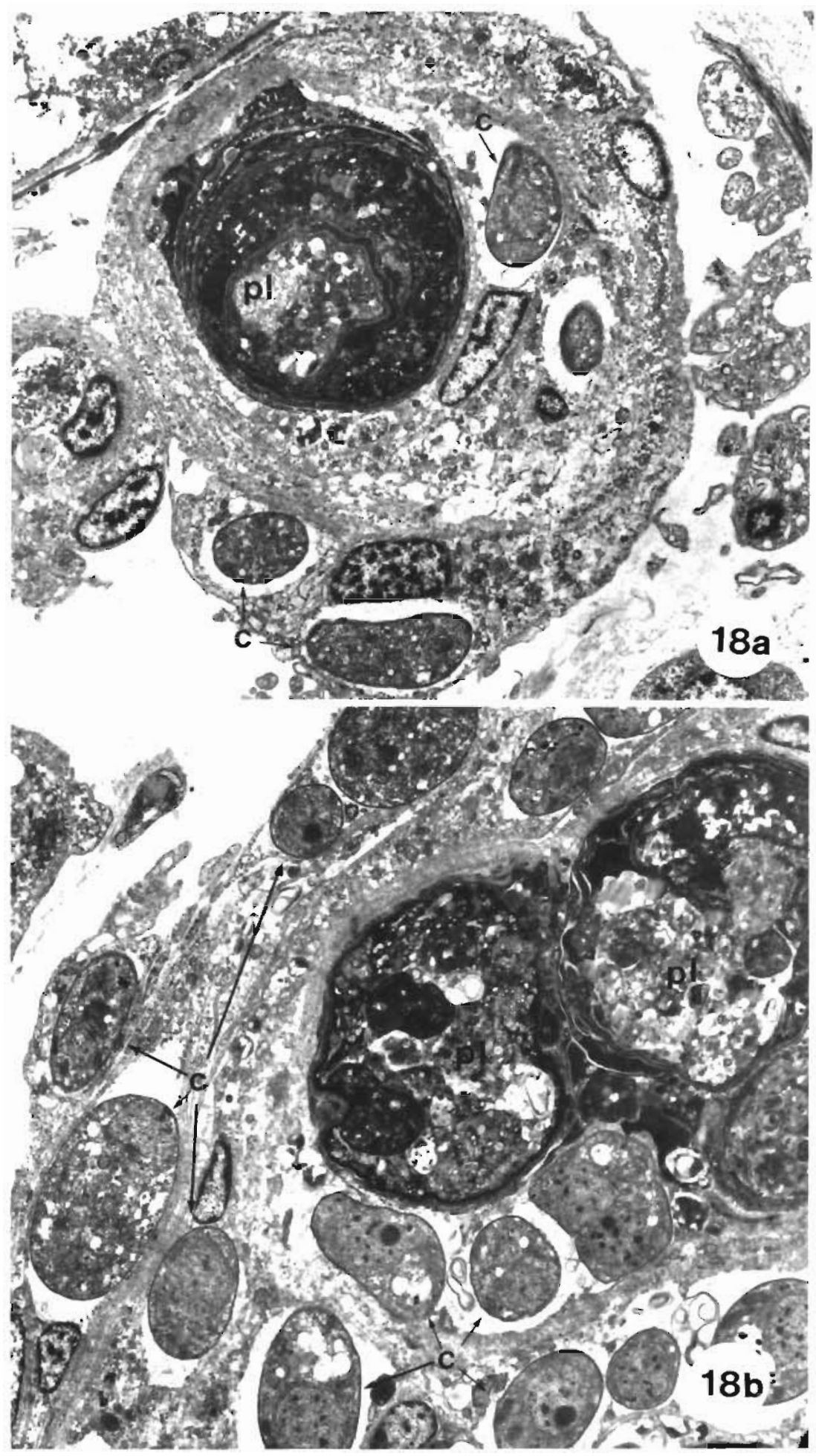

infected with Perkinsus marinus (= Dermocystıdıum marinum).

The ability to identify Perkinsus karlssonı within older lesions was difficult at both the light and electron microscope level due to the significant infiltration by ceroid-containing cells. McGladdery et al. (1991) ques- tioned the viability of P. karlssoni in lesions with extensive encapsulation and heavy cerond content. Indeed, Cheng (1981) noted that infiltration by brown cells or cerold-containing cells is possibly an attempt to remove degradation products of dead and moribund parasites, but in addition he also indicated that it may be 
an attempt to remove the metabolic by-products of successful parasites. It is therefore possible that the ceroid-containing cells present in the lesions observed in the bay scallops may be a response to the metabolic by-products of $P$. karlssoni which may remain unaffected by the host response and may even continue to multiply within the lesion.

Bay scallops did not demonstrate any tissue response to the presence of the coccidian parasite alone. In infected epithelial tissue the parasite was observed to occupy more than half of the host cell with the cell nucleus compressed to one end of the cell. The cytoplasm surrounding the parasite was vacuolated and it is suggested that the parasite resides within a parasitophorus vacuole that is surrounded by cytoplasm and an enveloping membrane Whether the parasite causes cell death is not known although it is feasible that normal cell function is affected as a result of distortion to the normal cell architecture. A lack of tissue response to an unidentified coccidian was also reported by Wolf (1977) in the ova of the blacklipped oyster. The intracellular habit of these parasites probably enables them to avoid the host response but if the parasite destroys the cell the exposed parasitic stagcs would then be susceptible to attack by the host. This is seen in littleneck clams infected with a coccidian where massive epithelial destruction elicited an intense inflammatory response (Morado et al. 1984). In infected bay scallops, however, the coccidian was observed to occur intercellularly in connective tissue with no apparent host response. The reasons for the lack of response to the coccidian by bay scallops in this study are unclear, but it can be speculated that this coccidian may be a highly successful parasite maintaining, in normal circumstances, a well-balanced relationship with the bay scallop. It is conceivable that this balance could be maintained by the parasite's ability to evade the suppressive activity of the host as is the case for other coccidian infections (Rose 1982).

The majority of Perkinsus karlssoni 'swirl' lesions were observed in the connective tissues but some were also found in the intestinal epithelium and mantle of heavily infected bay scallops. In oysters infected with $P$. marinus the epithelia was usually reported to be the least damaged tissue, even in advanced infections, since parasite multiplication occurred mainly in connective tissues or between the epithelial cells (Perkins 1976, 1993). This would also appear to be true for $P$. karlssoni since the ciliated border of the intestine remained intact and presumably functioned normally despite the host encapsulation response in the intestinal epithelium. The mantle epithelium was also invaded resulting in the formation of lesions. In some cases, the parasite was separated from the exterior either by a single cell layer of epithelium or a thick lesion wall when the epithelium was completely absent.

The primary portal of entry for Perkinsus marinus was reported to be the digestive epithelium, although entry was also suggested to occur through other epithelial surfaces (Sparks 1985), including the gill, either by direct penetration of epithelial cells or transport through the epithelium by haemocytes (Perkins 1993). It is possible that P. karlssoni may have invaded the bay scallop through the intestinal epithelium despite the presence of an intact ciliated border in the intestine. This may be explained by the routine sloughing and replacement of the digestive epithelium during the normal digestive cycle. Whether $P$. karlssoni leaves the bay scallop at the intestinal epithelium is unclear but it is possible that there would be minimal disruption of digestive epithelial cells by passage of the parasite out of the host as a result of the normal digestive cycle. Cheng (1981) also reported that haemocytes can move in either direction across the digestive epithelium and so it is equally possible that P. karlssoni could enter and exit the bay scallop at this site. Whether $P$. karlssoni enters and/or exits the bay scallop through the mantle epithelium in this study was also unclear but the extent of the host response would suggest that the parasite had been lodged in the mantle epithelium for some time.

In contrast, the coccidian parasite was observed to occur mainly in the kidney and epithelial tissues of the host. In heavy infections both the digestive tubules and intestinal epithelium of the bay scallop were severely infiltrated by the coccidian. In lightly infected individuals the columnar cells of the epithelium remained intact, whereas in some severely infected individuals the columnar cells of the intestinal epithelium and digestive tubules were totally destroyed and the parasite was observed in the lumen of both the intestine and digestive tubules. Whether the coccidian entered the bay scallop via the digestive epithelium, either through active penetration or being transported by haemocytes, is unclear. It is likely that once within the host the coccidian proliferates since the severity of infection increased with the length of time spent in the holding system. The parasite's predilection for the kidney and the digestive function of the latter would suggest that it is feasible for the coccidian to migrate from the digestive epithelium to the kidney. Once within the lumen of the renal tubules the coccidian could easily move into the gonoducts since they are continuous with the lumen of the kidney. Whether the coccidian actively exits the host through the digestive epithelium or during spawning, or remains within the host until the latter dies, is unclear although both routes could provide a means of exit for the coccidian and also Perkinsus karlssoni in concurrent infections. Obviously further 
work is required to elucidate the precise mechanisms of entry into/exit from the bay scallop.

In mixed infections parasitic lesions were most often observed in the connective tissues of various organs and had the characteristic 'swirl' configuration. At the light microscope level the coccidian parasite could be identified in some lesions. Ultrastructurally it was possible to observe a significant host response towards Perkinsus karlssoni but no apparent response against the coccidian despite its presence within the lesion. The coccidian parasites which were present outside the lesion did not elicit any host response suggesting the coccidians within the lesion are there by random chance alone and the inflammatory response observed is initiated by P. karlssoni. Once within the lesion the coccidian would be expected to be vulnerable to the lytic activities of the haemocytes although no evidence for this was observed during this study.

In this study no clear evidence of mortality has been attributed to the coccidian under 'normal' growing conditions for cultured bay scallops or in wild bay scallop stock. It is, however, concluded that the closed circulation system in which the bay scallops were held and the lack of a host response enabled the coccidian parasite to increase to epidemic proportions (Cawthorn et al. 1992). The potential detriment to the host by the coccidian appears to arise from occupation of host epithelial tissues disrupting normal cell function (Leibovitz et al. 1984, Getchell 1991, Karlsson 1991). Some care should therefore be exercised when bay scallops are maintained in closed circulation systems at elevated temperatures, for example during spawning in a hatchery environment, since this coccidian could present a threat to the population at risk.

Acknowledgements. We thank R. Maloney for his technical assistance and L. Hawkins for maintenance of the shellfish. In addition thanks are expressed to D. Groman for critically assessing the manuscript. This project was supported in part by funds awarded to R. J. Cawthorn from the Atlantic Fisheries Adjustments Programme for Aquaculture, the Atlantic Canada Opportunities Agency, and the Natural Sciences and Engineering Research Council of Canada.

\section{LITERATURE CITED}

Andrews, J. D. (1988). Epizootiology of the disease caused by the oyster pathogen Perkinsus marinus and its effect of the oyster industry. In: Fisher W. S. (ed.) Disease processes in marine bivalve molluscs. American Fisheries Society Special Publication 18, p. 47-63

Azevedo, C. (1989). Fine structure of Perkinsus atlanticus n. sp. (Apicomplexa, Perkinsea) parasite of the clam Ruditapes decussatus from Portugal. J. Parasitol. 75 (4): $627-635$

Azevedo, C. (1990). Fine structure of zoosporulation in
Perkinsus atlanticus (Apicomplexa, Perkinsea). Parasitol 100: $351-358$

Cawthorn, R. J., MacMillan, R. J., McGladdery, S. E. (1992) Epidemic of Pseudoklossia sp. (Apicomplexa) in bay scallops Argopecten irradians maintained in warm water recirculating facility. Fish Health Section/American Fisheries Society Newsletter 20 (1): 2

Chagot, D., Comps, M., Boulo, V., Ruano, F., Grizel, H. (1987) Histological study of the cellular reaction in Ruditapes decussatus infected by a protozoan. Aquaculture 67: $260-261$

Cheng, T. C. (1981). Bivalves. In: Ratcliffe, N. A., Rowley, A. F (eds.) Invertebrate blood cells. Academic Press, New York, p. $234-300$

Comps, M., Chagot, D. (1987). Une parasitose nouvelle chez la palourde Ruditapes decussatus L. C. r. Acad. Sci., Paris 304: $41-44$

Getchell, R. G. (1991). Diseases and parasites of scallops. In: Schumway, S. E. (ed.) Scallops. Biology, ecology and aquaculture. Developments in Aquaculture and Fisheries Science No. 21. Elsevier, Amsterdam, p. 471-494

Howard, D. W., Smith, C. S. (1983). Histological techniques for marine bivalve mollusks. NOAA Tech. Memo. NMFSF/NEC-25, $95 \mathrm{p}$.

Karlsson, J. D. (1991). Parasites of the bay scallop, Argopecten irradians Lamarck (1819). In: Schumway, S. E., Sandifer, P. A. (eds.) An international compendium of scallop biology and culture. World Aquaculture Workshop no. 1. World Aquaculture Society, Baton Rouge, p. 180-190

Lauckner, G. (1983). Diseases of molluscs: Bivalvia. In: Kinne, O. (ed.) Diseases of marine animals, Vol. II, Bivalvia and Scaphopoda. Biologische Anstalt Helgoland, Hamburg, p. $477-961$

Léger, L. (1897). Sur la presence de coccidies chez les molluscques-Lamellibranche. C. r. Acad. Soc. Biol. 49: 987-988

Léger, L., Duboscq, O. (1917). Pseudoklossia pectinis n. sp. et l'origine des adélaidées. Arch. Zool. exp. gen. Notes Rev. 56: $7-16$

Leibovitz, L., Schott, E. F., Karney, R. C. (1984). Diseases of wild, captive and cultured scallops. J. World Maricult. Soc. 15: $269-283$

Lester, R. J. G., Davis, G. H. (1981). A new Perkinsus species (Apicomplexa, Perkinsea) from the abalone Haliotis ruber. J. Invert. Pathol. 37: 181-187

Lester, R. J. G., Goggin, C. L., Sewell, K. B. (1990). Perkinsus in Australia. In: Perkins. F. O., Cheng. T. C. (eds.) Pathology in marine science. Academic Press, New York, p. $189-199$

Mackin, J. G. (1951). Histopathology of infection of Crassostrea virginica (Gmelin) by Dermocystidium marinum Mackin, Owen and Collier. Bull. mar. Sci. Gulf Caribb. 1: 72-87

Mackin, J. G., Owen, H. M., Collier, A. (1950). Preliminary note on the occurrence of a new Protistan parasite, Dermocystidium marinum $\mathrm{n}$. $\mathrm{sp}$. in Crassostrea virginica (Gmelin). Science 111 (2883): 328-329

McGladdery, S. E., Cawthorn, R. J., Bradford, B. C. (1991). Perkinsus karlssoni n. sp. (Apicomplexa) in bay scallops Argopecten irradians. Dis. aquat. Org. 10: 127-137

Meyers, T. R. (1981). Endemic diseases of cultured shellfish of Long Island, New York: adult and juvenile American oysters (Crassostrea virginica) and hard clams (Mercenaria). Aquaculture 22: 305-330

Morado, J. F., Sparks, A. K., Reed, S. K. (1984). A coccidian infection of the kidney of the native littleneck clam, Protothaca staminea. J. Invert. Pathol 43: 207-217 
Perkins, F. O. (1976). Dermocystidium marinum infection in oysters Mar. Fish. Rev. Pap. 1207, 38 (10): 19-21

Perkins, F. O. (1993). Infectious diseases of molluscs. In Couch. J. A., Fournie, J. W. (eds.) Advances in fisheries science. Pathobiology of marne and estuarine organisms CRC Press, Boca Raton, p. 255-287

Rose, M. E. (1982). Host immune responses. In: Long, P. L. (ed.) The biology of the coccidia. University Park Press, Baltimore, p. 329-371

Responsible Subject Editor: A. K. Sparks, Seattle, Washington, USA
Sparks, A. K. (1985). Synopsis of invertebrate pathology. Exclusive of insects. Elsevier, Amsterdam

Tige, G., Comps, M., Grizel. H. (1977). Presence d'une coccidie parasite du rein chez Ostrea edulis L. Rev. Trav. Inst. Pèches Marit. 41(3): 223-225

Wolf, P. H. (1977). An unidentified protistan parasite in the ova of the blacklipped oyster, Crassostrea echinata from Northern Australia. J. Invert. Pathol. 29: $244-246$

Manuscript first received: April 16, 1993

Revised version accepted: July 27, 1993 